\title{
Effect of Supplier Relationship Management on Humanitarian Supply Chain Performance at the World Food Programme in Somalia
}

\author{
Kingsford M. Rucha \\ Lecturer; Department of Management Science, \\ School of Business, University of Nairobi-Kenya \\ Amina Nassor Abdallah \\ Department of Management Science, \\ School of Business, University of Nairobi-Kenya
}

doi: 10.19044/esj.2017.v13n16p250 URL:http://dx.doi.org/10.19044/esj.2017.v13n16p250

\begin{abstract}
The study sought to unfold the relationship between Supplier Relationship Management on supply chain in humanitarian organizations which is often difficult because of the multi-groups involved (military, government, Non-governmental Organizations). In humanitarian organizations the "customer" is the donor or supplier of goods. The study was conducted at the World Food Programme (WFP) which started operating in Somalia in 1967 and focusing on rural agricultural development and school feeding projects. At the onset of WFP operations, the conflict escalated and the humanitarian needs expanded as well. Today the WFP Somalia goal is to address basic food needs, strengthen coping mechanisms and support the efforts to achieve food security of vulnerable Somalis. The organization has its regional office in charge of operations and supply chain in Nairobi as well as the Somalia liaison office. There are rare studies focusing on supply chain relationship among humanitarian organizations particularly on the challenges of getting supplies on time due financial and other supply chain constraints. This is the gap this study sought to address. In order to achieve the objectives, the population of the study was the WFP employees (senior and the supply chain staff) in both the regional and the liaison office and the WFP food suppliers based in Nairobi. The sample comprised of 87 WFP employees and 7 personnel from the WFP food supplier family. Data was collected from 63 respondents who filled and returned the questionnaires representing a response rate rate of $72 \%$. Multiple regression analysis was used to analyse the data collected in order to meet the objectives of the study. The results revealed that WFP continuously trains employees from the supply chain department and has
\end{abstract}


mechanisms for ensuring suppliers conform to quality standards. It was also found that ICT is used in the execution and management of purchase orders. On WFP humanitarian supply chain performance, results indicated that WFP Somalia delivers defect free food supplies to beneficiaries by working closely with the internal staff and the logistics operators. The study recommends that WFP's management should begin rewarding suppliers who share information for effective supply chain management. The organization should not only have multiple supply tiers but should also be well vast with each tiers risk profile to enable the organization mitigate any unforeseen events that may affect delivery of supplies especially during emergencies.

Keywords: Procurement, operations management, supplier relationship, humanitarian supply chain

\section{Introduction}

Supplier Relationship Management (SRM) is a comprehensive approach to managing an organization's interactions with the firms that supply the products and services it uses (Lamming, 2005). SRM plays an important role in the reduction of costs and the optimization of performance in organizations. SRM is understood as the sourcing policybased design of strategic and operational procurement processes as well as the configuration of the supplier management (Appelfeller \& Buchholz, 2005). SRM includes both business practices and software and is part of the information flow component of supply chain management (SCM). SRM practices create a common frame of reference to enable effective communication between an enterprise and suppliers who may use quite different business practices and terminology. As a result, SRM increases the efficiency of processes associated with acquiring goods and services, managing inventory, and processing materials (McLachlin \& Larson, 2011).).

Theories underpinning this study are Social Exchange Theory (SET), Resource Dependency Theory (RDT) and Theory of Dual Economies (TDE). SET attempts to study inter-organizational relationships from the dyadic perspective, concentrating on the social structure of the relationship rather than the transaction (Homans, 1958). SET posits that all human relationships are formed by the use of a subjective cost-benefit analysis and the comparison of alternatives. As a result actors will remain in a relationship as long as there is value to be had (Cropanzano \& Mitchell, 2005). The Resource Dependency Theory (RDT) posits that no single firm has all the resources and functions needed to operate successful. This therefore means that organizations have to enter into exchange relationships with other organizations. 
Theory of Dual Economies posits that the dual economy would help large firms survive in world of uncertainty and flux through shifting most of the production and therefore certain risks to the secondary actor. Because small suppliers want to come out of the periphery, this has triggered new buyer-supplier relationships (Berger \& Piore, 1980).

World Food Programme (WFP) is providing school meals to relieve hunger and boost enrolment rates, particular of girls by providing take-home family rations for girls attending schools to incentivize parents (WFP, 2015). According to Clarke and Herbst (1997), WFP started operating in Somalia in 1967, focusing on rural agricultural development and school feeding projects. The onset of conflict escalated humanitarian needs and WFP expanded its programmes. WFP Somalia aims to address basic food needs, strengthen coping mechanisms and support the efforts to achieve food security of vulnerable Somalis so they can cope more effectively with hardships. This study aims to investigate how WFP manages the relationship with its suppliers and the effect this has on its performance.

\section{Supplier Relationship Management (SRM)}

In today's economies, many organizations get a large majority of their product value from their supply base. Over the past century, outsourcing of services, materials, and manufacturing has grown tremendously as companies have implemented more cost- effective and leaner operating models (Cannon \& Homburg, 2001). According to Cox, (2004), purchased items represent approximately $60 \%$ of the total cost of goods sold. This trend is expected to continue as companies have realized the necessity of focusing their resources on their core businesses and competencies and on outsourcing auxiliary functions in which they do not have a competitive advantage. This will allow companies to reduce costs and enhance customer responsiveness as well as optimize resource utilization. As a result of this, many organizations will come to rely heavily on, not only securing the correct supply base, but also on maintaining strategic relationships with suppliers. This is especially important in the procurement of direct, strategic materials, which are procured from a small number of trusted vendors (Lascelles \& Dale, 1989).

SRM allows for the development and maintenance of these strategic relationships with key suppliers and forces enterprises to adopt a new way of thinking about the supply chain and supply chain transparency. Rather than seeking the greatest short-term advantage in each transaction, suppliers and their customer organizations seek to work together in close collaboration for long-term mutual advantage (Shin, Collier \& Wilson, 2000). These relationships require a new level of trust 
and commitment that, in past the absent. The trust and commitment mentioned above, motivates suppliers to share their manufacturing, engineering, transport expertise with the organization. By gaining access to this intellectual capital, the organization will be able to design better products and implement leaner and more efficient manufacturing processes. Supplier expertise on transport economics can also be employed by the organization to cut distribution costs and get to market quicker. Cost reductions can be passed onto consumers as decreased prices and this, together with increased speed to market, increases the organizations profitability and strategic competitive position (Shin, Collier \& Wilson, 2000).

\section{Humanitarian Supply Chain (HSC)}

Humanitarian supply chain is the process of getting aid in the form of goods and services to the beneficiaries requiring the goods. Fritz Institute (2006) defines the term humanitarian supply chain as a process that integrates coordinates and controls the movement of materials, goods and related information from suppliers and donors to meet beneficiary requirements in a timely manner. Humanitarian supply chain covers disaster relief as well as continuous support for developing regions. Thomas (2004) explains that humanitarian supply chain entails the processes of planning, implementing and controlling the efficient, cost effective flow and storage of goods and materials as well as related information from the point of origin to the point of consumption for the purpose of alleviating the suffering of vulnerable people. The function encompasses a range of activities, including preparedness, planning, procurement, transport, warehousing tracking and tracing, customs and clearance.

Humanitarian supply chain shares some common aspects with their commercial supply chain in that in both sides the most must be obtained out of scarce resources and limited budgets. Additionally in HSC, it is important to reach more beneficiaries in need and serve them more quickly. Also, donors increasingly demand accountability, transparency and value for money in return for their sponsorship. Meeting these higher challenging performance and accountability standards requires humanitarian organizations to be more professional in their approach to managing their operations (Thomas \& Kopczak, 2005) as 80 percent of humanitarian aid operations comprise supply chain management (Van Wassenhove, 2006).

There exist two types of risk that affect the effectiveness and the efficiency of humanitarian supply chains: the disruption risk and the coordination risk. Whereas the disruption risk relates to complexity and 
geographical dispersion, the coordination risk refers to ensuring both demand and supply match with each other, despite the pressures of costconscious lean and leaner designs. In order to eliminate the coordination risk and achieve economies of scale Schulz and Blecken (2010) suggest the use of collaboration amongst key actors, such as between service providers and humanitarian relief organizations.

\section{World Food Programme (WFP)}

The World Food Programme is the world's largest humanitarian agency fighting hunger worldwide. In emergencies, the agency gets food to where it is needed, saving the lives of victims of war, civil conflict and natural disasters. After the cause of an emergency has passed, WFP uses food to help communities rebuild their shattered lives (WFP, 2015). WFP is part of the United Nations system and is voluntarily funded. Created in 1961, WFP pursues a vision of the world in which every man, woman and child has access at all times to the food needed for an active and healthy life. WFP works towards that vision with sister UN agencies; the Food and Agriculture Organization (FAO) and the International Fund for Agricultural Development (IFAD) as well as other government, UN and NGO partners. WFP reaches more than 80 million people with food assistance in 75 countries each year (WFP, 2015).

In Somalia, a country ravaged by unending conflicts, WFP provides school meals to relieve hunger and boost enrolment rates, particular of girls by providing take-home family rations for girls attending schools to incentivize parents (WFP, 2015). According to Clarke and Herbst (1997), WFP started operating in Somalia in 1967, focusing on rural agricultural development and school feeding projects. The onset of conflict escalated humanitarian needs and WFP expanded its programmes. WFP Somalia aims to address basic food needs, strengthen coping mechanisms and support the efforts to achieve food security of vulnerable Somalis so they can cope more effectively with hardships.

WFP's programmes range from relief, which is provided during emergencies, to activities designed to strengthen the resilience of households against future shocks, such as droughts and floods (WFP, 2015). WFP is now using a targeted approach to relief assistance for people and communities in crisis, including social safety nets and livelihood support projects, some of which are provided on a seasonal basis when needs are greatest, such as between harvests. The organization is also concentrating on nutritional programming. The nutrition strategy in Somalia focuses on treatment of both chronic and acute malnutrition during the current emergency, as well as implementing activities that concentrate on preventing people from becoming malnourished. During 
lean or dry seasons in highly food insecure areas, WFP provides family rations to malnourished mothers and young children who are part of our supplementary feeding programmes (WFP, 2015). WFP has regional offices around the world as well as country offices. The regional office overseeing operations within the region is based in Nairobi as well as the Somalia liaison office. For food, WFP operates on three levels: Headquarters, regional and local. WFP's regional and country offices have delegated authorities to carry out their own procurement up to established financial limits. Purchases beyond these limits are conducted by WFP Headquarters Procurement (WFP, 2015).

In WFP, distributing safe and healthy food commodities is a collaborative effort throughout the entire supply chain, which involves suppliers, buyers, and governments at country, regional, and global levels. WFP endorses a comprehensive food safety and quality management system to control and manage the quality of the food delivered, from primary production to food distribution and final consumption. The system promotes adherence to standards in the form of food specifications, monitoring of vendors' performance (food suppliers, laboratories and inspection companies), improving the nutritional value of the food commodities and specialized nutrition products, and capacity building of actors throughout the supply chain. The World Food Programme's (WFP) Purchase for Progress (P4P) pilot program connects smallholder farmers (SHF) to markets using WFP's position as a major staple food buyer. WFP purchases more than 75 percent of its food annually from developing countries (WFP, 2015).

WFP aims to improve integrated supply chain for food commodities by better linking demand forecasting, supply strategies and logistics capacity. The Logistics Development Unit (LDU) supports the Procurement Division in developing an integrated process, an optimal supply and delivery plan and a clear sourcing strategy for each region. LDU is the logistics and supply chain research and innovation division located within WFP's Logistics Division. By bringing together technology, expertise and best practices from humanitarian field, academia, private sector and government partners, LDU works across WFP divisions to develop supply chain strategies and solutions that increase operational efficiency and effectiveness, provide visibility in supply chains, build internal and partner humanitarian response capacity and promote a culture of continuous improvement. The organization has a supply chain performance management scorecard covering end-to-end operations from sourcing to final delivery of food to beneficiaries (WFP, 2015). 


\section{Supply Chain Performance}

The primary goal in relief operations is to minimize the response time (to deliver supplies to the areas as they are needed). Moreover, relief efforts generally operate on limited funds, which increase the importance of efficient (low cost) inventory management systems (Beamon \& Balcik, 2008). When disasters strike, relief organizations respond by delivering aid to those in need. Their supply chains must be both fast and agile, responding to sudden-onset disasters which may occur in cities such as New Orleans, or on the other side of the globe in places like rural Pakistan. Since 2004, two large-scale natural disasters have captured the attention of the international media: the 2004 tsunami and the 2005 earthquake in South Asia. Disasters of this magnitude cause donors, beneficiaries, and the media to closely monitor how quickly and efficiently relief organizations are able to respond. A disaster response operation involves trade-offs of speed, cost, and accuracy with regard to the type of goods that are delivered and their quantities. Balancing these trade-offs requires a means of measuring supply chain performance; however, the inability to centrally capture time and cost data related to the procurement and distribution of goods has prevented a systematic process of performance measurement from being implemented (Beamon \& Balcik, 2008).

Critical operations performance objectives are crucial factors that are strategically important to organizations. Being strategically important means that the performance objectives have to be considered as strategic goals to be achieved and the primary aim of the operations function is to deploy the appropriate resources to support the achievement of those goals. Typically, the operations performance objectives are specifically related to satisfying customers requirements. In general, the fundamental performance objectives that apply to all types of organization and are closely related to customer satisfaction requirements are speed, dependability, flexibility, quality, and cost (Bhagwat, \& Sharma, 2007). Speed means doing things quickly. It is about delivering goods and services to customers as fast as possible. This involves making quick decisions and rapidly moving materials and information inside the operations. Dependability means doing things on time and as promised. It is about developing trustworthiness. Dependability can be achieved through the use of reliable equipments, effective communication, efficient scheduling systems, motivated workforce and transparency of processes (Batista, 2009).

Flexibility is about being able to change the operations to fulfill new requirements. As requirements can change over time, organizations need to develop operations ability to introduce new or modified products 
and services. Flexibility also involves volume flexibility (the ability to change volume of output over time) and delivery flexibility (the ability to change delivery time). Flexibility can be achieved to the use of more versatile equipments, suppliers with good flexibility performance and multi-skilled workforce among others (Bhagwat, \& Sharma, 2007). The quality objective can be achieved by the provision of error-free products or services that fulfill customer requirements. This requires skilled workforce, adequate job specifications, proper technologies, and effective communication. Lower cost of production or service delivery reflects to the customer in form of lower price. Cost reduction can be achieved by developing good relationships with suppliers, good negotiation of supplying contracts, getting the right mix of resources and facilities as inputs (Batista, 2009).

\section{Research Problem}

Coordination in humanitarian organizations is often difficult because of the many groups involved (military, government, NGO's), and often inadequate infrastructure. Moreover, in humanitarian supply chain, the "customer" is usually the donor or supplier of goods, rather than the recipient of the aid the programme is designed to help. These donors must be sold by showing the donation is being used properly. Although aid effectiveness as an operational goal of humanitarian organizations is often criticized since it overlooks other goals such as equity, this does not mean that efficiency should be discarded. This is because beneficiaries require humanitarian agencies to demonstrate operational efficiency especially when disasters strike since this can save lives. This means that an organization that does not have a supplier relationship management strategy may fail to attain operational efficiency hence failing to achieve their main objective (saving lives) due to delayed delivery, high costs and poor quality. This therefore calls for supply relationship management on the part of humanitarian agencies.

Various studies have been conducted on supplier relationship management. Samuel (2014) conducted an empirical study on the effect of buyer- supplier partnership on better service delivery within nongovernmental organizations involved in humanitarian work, taking the case of World Vision International. Results showed that there were longterm supplier relations in sourcing. Paiva, Phonlor and D'avila (2008) analyzed the influence of the buyer-supplier relationship continuity on service performance among companies that are users of international maritime transport belonging to the machinery and food industries. Results showed that traditional performance criteria like delivery, dependability and cost clearly are influenced by the aspects related to the 
management of the relationship. This includes information exchange, trust and interaction between the parts.

Mettler and Rohner (2009) studied supplier relationship management taking a case study in the context of health care by illustrating the impact of the implementation of SRM principles in a leading Swiss hospital. The findings from the case study showed that the hospital was applying industrial supply management practices and tools. Locally, Ndambuki (2013) studied the relationship between supply chain integration and supply chain performance of international humanitarian organizations in Kenya. Results showed that information sharing resulted in reduced lead-time in the organizations, improving supply chain performance and easy order processing while integration resulted in increased efficiency. However, no local study has focused on supply chain relationship among humanitarian organizations; despite the challenges they get in getting supplies on time due to financing and other constraints, a gap that the present study aimed to fill by studying supplier relationship management in humanitarian supply chain at the World Food Programme in Somalia. The study aimed to answer the following question; what is the effect of supplier relationship management on the service performance of World Food Programme in Somalia?

\section{Research Objective}

The objective of this study was to investigate the effect of supplier relationship management on supply chain performance at the World Food Programme in Somalia.

\section{Literature Review}

Organizations that practice SRM end up improving their supply chain performance. Continuous maintenance of a good relationship with your suppliers will protect an organization from the problems of quality, increase efficiency and hence improve performance. This applies to all organizations, whether commercial or humanitarian. Without SRM, operations will slow down or even stop when business is booming because suppliers will tend to prioritize customers who have maintained a good relationship with them. With SRM, the supplier is made part of the organization and will always keep that particular organization in mind. Organizations should develop and maintain long term relationships with suppliers by sharing information, managing the supplier performance and using information technology in supply chain management. 


\section{Data Analysis}

The data was analyzed using the IBM Statistical Program for Social Sciences ((SPSS) version 21. Descriptive statistics was used to summarize the data. This included percentages and frequencies. Tables, pie charts and other graphs were used to present the data collected for ease of understanding. Measures of central tendency were used (mean, standard deviation median, mode and percentages). Multivariate regression was used to determine the effect of SRM on service performance. The regression model was;

$$
Y=\beta_{0}+\beta_{1} X_{1}+\beta_{2} X_{2}+\beta_{3} X_{3}+\beta_{4} X_{4}+\beta_{5} X_{5}+\varepsilon
$$
and cost)

Where: $\quad Y=$ Performance (quality, cost, dependability, flexibility

$\mathrm{X}_{1}=$ Information Sharing

$\mathrm{X}_{2}=$ Multiple Tiers for Value Generation

$\mathrm{X}_{3}=$ Knowledge Management

$\mathrm{X}_{4}=$ Supplier Performance Management

$\mathrm{X}_{5}=$ IT and Supplier Relationship Management, where;

$\varepsilon=$ Error term/Erroneous variables. $\beta_{0}=$ constant/the minimum change in $\mathrm{Y}$ when the rest of the variables are held at a constant zero. $\beta_{1}=$ measures the rate of change in Performance as a result of the rate of change in information sharing. $\beta_{2}=$ measures the rate of change in Performance as a result of the rate of change in Multiple Tiers for Value Generation. $\beta_{3}=$ measures the rate of change in Performance as a result of the rate of change in Knowledge Management. $\beta_{4}=$ measures the rate of change in Performance as a result of the rate of change in Supplier Performance Management. $\beta_{5}=$ measures the rate of change in Performance as a result of the rate of change in IT in Supplier Relationship Management

\section{Results and Discussion}

This chapter presents analysis and findings of the study as set out in the research methodology. The results of the investigation of the effect of supplier relationship management on humanitarian supply chain performance at the World Food Programme Somalia are presented. Primary data was gathered from questionnaires and interviews. Likert type questions were included whereby respondents indicated the extent to which the variables were practiced in a five point Likert scale.

\section{Response Rate}

The study targeted 87 respondents in collecting data with regard the effect of supplier relationship management on humanitarian supply chain performance at the World Food Programme Somalia. Of these, 63 
questionnaires were filled and returned while 5 suppliers were interviewed. This gave a response rate of $72 \%$ as shown on Figure 1.

Figure 1: Response Rate

Response Rate

Not responded $28 \% \quad$ Responded $72 \%$

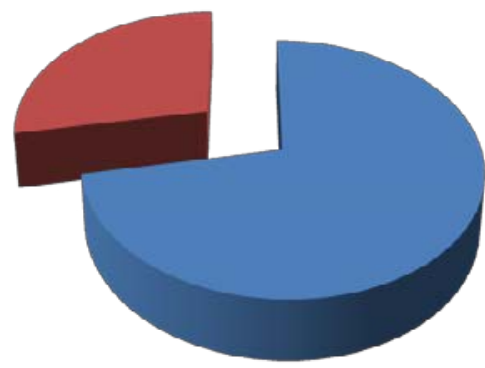

\section{Supplier Relationship Management} Information Sharing

Table 1: Information Sharing

\begin{tabular}{ccc}
\hline My organization always shares information with suppliers & Mean & Std. Dev \\
My organization has put in place measures for effective information & 3.01 & 1.11 \\
sharing with subpliers & 1.45 \\
Our suppliers always inform us in advance when they expect & 3.02 & 1.01 \\
disrubtions in subvlies & 2.76 & 1.12 \\
My organization rewards suppliers who shares information & 3.24 & 1.09 \\
\hline At WFP, procurement employees freely interact with suppliers & At 5\% sign. level
\end{tabular}
At 5\% sign. level

From the findings, whether the organization rewards suppliers who shares information had a mean of 2.76, whether our suppliers always inform us in advance when they expect disruptions in supplies had a mean of 3.02, whether at WFP, procurement employees freely interact with suppliers had a mean of 3.24, whether the organization has put in place measures for effective information sharing with suppliers had a mean of 3.89 while whether the organization always shares information with suppliers had the highest mean of 4.01. According to Ounnar, Pujo, Mekaouche and Giambiasi (2007), organizations are beginning to understand and accept that if they do not open up to suppliers about their entire approach to cost investment return, it will be difficult for suppliers to contribute innovative ways to save money for both sides. With strategic information sharing between an organization and its suppliers, innovation is enhanced where suppliers are able to 
save significant money for an organization and share the cost savings for the benefit of all.

Extent of Influence of Information Sharing

Table 2: Extent of Influence of Information Sharing

\begin{tabular}{ccc}
\hline Extent & Frequency & Percent \\
Very great extent & 21 & 33 \\
Great extent & 30 & 48 \\
Moderate extent & 9 & 14 \\
Little extent & 3 & 5 \\
Total & $\mathbf{6 3}$ & $\mathbf{1 0 0}$ \\
\hline
\end{tabular}

At 5\% sign. level

From the findings, majority of the respondents, $48 \%$ said that information sharing influences humanitarian supply chain performance to a great extent followed by 33\% who said that information sharing influences humanitarian supply chain performance to a very great extent

\section{Multiple Tiers Value Generation}

Table 3: Multiple Tiers for Value Generation

\begin{tabular}{|c|c|c|}
\hline & Mean & Std. Dev \\
\hline WFP has multiple tier suppliers & 3.95 & 1.13 \\
\hline $\begin{array}{c}\text { My organization ensures efficient exchange of information across } \\
\text { the multiple supplier tiers }\end{array}$ & 3.78 & 0.76 \\
\hline $\begin{array}{l}\text { The organization has put in place enough resources to } \\
\text { manage multiple tier suppliers to avoid disruptions }\end{array}$ & 3.22 & 1.23 \\
\hline $\begin{array}{l}\text { The organization has trained employees on managing its multiple } \\
\text { tier suppliers }\end{array}$ & 3.12 & 0.67 \\
\hline The organization understands the risk profiles of each supply tier & 3.02 & 1.34 \\
\hline $\begin{array}{l}\text { The organization understands the number of up or down- } \\
\text { stream layers across the supply chain }\end{array}$ & 3.21 & 0.56 \\
\hline $\begin{array}{l}\text { The organization understands the number of agents present in } \\
\text { each tier. }\end{array}$ & 3.56 & 0.98 \\
\hline
\end{tabular}

At 5\% sign. level

From the findings, whether the organization understands the risk profiles of each tier had a mean of 3.02, whether the organization has trained employees on managing its multiple tier suppliers had a mean of 3.12, whether the organization understands the number of up or downstream layers across the supply chain had a mean of 3.21 while whether the organization has put in place enough resources to manage multiple tier suppliers to avoid disruptions had a mean of 3.22. Whether the organization understands the number of agents present in each tier had a mean of 3.56, whether the organization ensures efficient 
exchange of information across the tiers had a mean of 3.78 while whether WFP has multiple tier suppliers had the highest mean of 3.95. This means that even though the organization had multiple supplier tiers for value generation, it did not know well the risk profile of each tier.

According to Choy, Lee and Lo (2002), developing a collaborative relationship with a supplier does not occur overnight. It takes time to strengthen the various levels of communication. However, the same strategies that applied to an organization's first-tier supplier can also be applied to multiple tiers in the supply chain. As the market of tomorrow may be driven by competing supply chains, the ability to transfer those relationship skills to multiple tiers is a major advantage for organizations. Multi-tier supplier relationships are unique because they provide an opportunity for the organization and its suppliers to discuss mutual or company values (Shin, Collier \& Wilson, 2000).

\section{Extent of Influence of Multiple Tiers}

Table 4: Extent of Influence of Multiple Tiers

\begin{tabular}{ccc}
\hline Extent & Frequency & Percent \\
Very great extent & 15 & 24 \\
Great extent & 29 & 46 \\
Moderate extent & 15 & 24 \\
Little extent & 3 & 5 \\
No extent at all & 1 & 1 \\
Total & $\mathbf{6 3}$ & $\mathbf{1 0 0}$ \\
\hline
\end{tabular}

At 5\% sign. level

From the findings, $70 \%$ of the respondents said that multiple tiers influenced humanitarian supply chain performance to a great extent.

\section{Knowledge Management}

Table 5: Knowledge Management

Mean Std. Dev.

My organization ensures that all employees are knowledgeable in $3.46 \quad 1.12$ most of the organization aspects

$\begin{array}{lllllll}\text { WFP continuously trains employees from then } & 3.67 & 1.45\end{array}$ procurement department

WFP has put in place mechanisms for knowledge management

$3.44 \quad 1.01$

WFP encourages individual learning

$3.12 \quad 1.11$

At 5\% sign. level

From the findings, whether WFP encourages individual learning had a mean of 3.12, whether WFP has put in place mechanisms for knowledge management had a mean of 3.44 , whether the organization 
ensures that all employees are knowledgeable in most of the organization aspects had a mean of 3.46 while whether WFP continuously trains employees from then procurement department had the highest mean of 3.67. This means the organization invests resources in the training of its employees in the procurement department. The findings are in agreement Inkpen and Dinur (1998) who posits that knowledge management is a critical part of supplier relationships. It can be a major advantage for a party that knows more about the other. According to Laudon and Laudon (2004), the approach to relationship management must be a team approach, not only to capture knowledge but also to ensure that the organization is not dependent on an individual to make the right decisions, have the right information or manage relationships.

\section{Extent of Influence of Knowledge Management}

The study sought the respondents' opinion about the extent to which Knowledge Management influences humanitarian supply chain performance.

Table 6: Extent of Influence of Knowledge Management

\begin{tabular}{ccc}
\hline Extent & Frequency & Percent \\
\hline Very great extent & 17 & 27 \\
Great extent & 29 & 46 \\
Moderate extent & 11 & 17 \\
Little extent & 5 & 8 \\
No extent at all & 1 & 2 \\
Total & $\mathbf{6 3}$ & $\mathbf{1 0 0}$ \\
\hline
\end{tabular}

At 5\% sign. level

From the findings, majority of the respondents, $73 \%$ said that Knowledge Management influences humanitarian supply chain performance to a great extent.

\section{Supplier Performance Management}

The study sought to find out about Supplier Performance Management in supplier relationship management. 
Table 7: Supplier Performance Management

\begin{tabular}{lccc}
\hline & Mean & Std. Dev. \\
\hline $\begin{array}{l}\text { WFP is keen on suppliers of critical commodities like food } \\
\text { WFP has put in place mechanisms to evaluate the performance of its } \\
\text { suppliers }\end{array}$ & 4.83 & 0.38 \\
WFP has mechanisms to $\begin{array}{c}\text { ensure suppliers conform to quality } \\
\text { standards }\end{array}$ & 4.66 & 0.48 \\
WFP has mechanisms to ensure suppliers comply with standard & 3.91 & 1.01 \\
$\begin{array}{l}\text { prices } \\
\text { WFP has mechanisms to ensure suppliers conform to lead-time }\end{array}$ & 4.40 & 0.65 \\
\hline \begin{tabular}{l} 
standards \\
\hline
\end{tabular}
\end{tabular}

At 5\% sign. level

From the findings, whether WFP has mechanisms to ensure suppliers comply with standard prices had a mean of 3.91, whether WFP has mechanisms to ensure suppliers conform to lead-time standards had a mean of 4.40, whether WFP has put in place mechanisms to evaluate the performance of its suppliers had a mean of 4.46, whether WFP has mechanisms to ensure suppliers conform to quality standards had a mean of 4.66 while whether WFP is keen on suppliers of critical commodities like food had the highest mean of 4.83. According to Tan, Kannan and Handfield (1998), measurement of supplier performance is a step in the right direction. Focusing on critical suppliers or suppliers that constitute the largest portion of spending enables a company to identify and manage those performance issues that could have the most immediate and greatest impact on its operations and its perception in the market.

\section{Extent of Influence of Supplier Performance Management}

The study sought the respondents' opinion about the extent to which Supplier Performance Management influences humanitarian supply chain performance.

Table 8: Extent of Influence of Supplier Performance Management

\begin{tabular}{ccc}
\hline Extent & Frequency & Percent \\
\hline Very great extent & 25 & 40 \\
Great extent & 32 & 51 \\
Moderate extent & 5 & 8 \\
Little extent & 1 & 1 \\
Total & $\mathbf{6 3}$ & $\mathbf{1 0 0}$ \\
\hline
\end{tabular}

At 5\% sign. level 
From the findings, majority of the respondents, 91\% said that Supplier Performance Management influences humanitarian supply chain performance to a great extent.

\section{Information Technology}

The study sought to find out about Information Technology in supplier relationship management.

Table 9: Information Technology

\begin{tabular}{ccc}
\hline & Mean & Std. Dev. \\
\hline $\begin{array}{c}\text { WFP's supply chain management system is IT integrated } \\
\text { WFP has installed software to ensures real time sharing } \\
\text { of information with suppliers }\end{array}$ & 4.57 & 0.49 \\
$\quad \begin{array}{c}\text { At WFP, technology tools are used to determine who to buy from } \\
\text { and what to buy from them }\end{array}$ & 3.54 & 0.49 \\
$\quad \begin{array}{c}\text { At WFP, IT is used in the execution and management of } \\
\quad \text { purchase orders }\end{array}$ & 4.66 & 0.48 \\
$\quad$ At WFP , a Web-based catalogue system is used & 3.91 & 1.01 \\
\hline At 5\% sign. level & &
\end{tabular}

From the findings, whether at WFP, technology tools are used to determine who to buy from and what to buy from them had a mean of 3.54, whether at WFP a Web-based catalogue system is used had a mean of 3.91, whether WFP has installed software to ensures real time sharing of information with suppliers had a mean of 4.40 , whether WFP's supply chain management system is IT integrated had a mean of 4.57 and whether at WFP, IT is used in the execution and management of purchase orders had the highest mean of 4.66. According to Bowersox, Closs and Cooper (2002), the integration of technology in SRM applications allows co-operating parties to conceptualize and codify best practices into their interaction, as well as enforce compliance across multiple divisions and locations. SRM partners can use technology to allow each other to see information they might have kept secret from one another before, such as real-time changes in prices paid for components or changes in actual shipping costs.

\section{Extent of Influence of Information Technology}

The study sought the respondents' opinion about the extent to which Information Technology influences humanitarian supply chain performance. 
Table 10: Extent of Influence of Information Technology

\begin{tabular}{ccc}
\hline Extent & Frequency & Percent \\
\hline Very great extent & 22 & 35 \\
Great extent & 30 & 48 \\
Moderate extent & 9 & 14 \\
Little extent & 2 & 3 \\
Total & $\mathbf{6 3}$ & $\mathbf{1 0 0}$ \\
\hline
\end{tabular}

At 5\% sign. Level

From the findings, majority of the respondents, $83 \%$ said that Information Technology influences humanitarian supply chain performance to a great extent.

\section{Humanitarian Supply Chain Performance}

The study sought to find out the performance of WFP's humanitarian supply chain performance in terms of quality, cost, dependability, flexibility and cost. Results are given on Table 12.

Table 11: Humanitarian Supply Chain Performance

\begin{tabular}{ccc}
\hline & Mean & Std. Dev. \\
\hline WFP Somalia delivers defect free food supplies to beneficiaries & 3.51 & 1.15 \\
Beneficiaries are satisfied with the quality of our food supplies & 3.17 & 1.12 \\
There are no cases of diseases affecting the beneficiaries due to & 3.69 & 1.11 \\
$\quad$ poor quality food supplies & & \\
$\quad$ Our food supplies reach beneficiaries in time & 2.96 & 1.34 \\
At WFP Somalia, there are no cases of delayed supplies & 3.37 & 1.03 \\
There are no cases of starvation among beneficiaries due to & 3.43 & 1.12 \\
$\quad$ delayed food supplies & & \\
WFP Somalia beneficiaries get food supplies when promised & 2.90 & 1.42 \\
WFP has reduced significantly the cost of delivering food supplies & 3.34 & 1.19 \\
WFP Somalia has great minimized the time between the order and & 3.10 & 1.66 \\
the availability of food supplies to beneficiaries & & \\
WFP Somalia uses versatile equipment & 3.12 & 2.11 \\
WFP suppliers have flexibility performance & 3.22 & 1.21 \\
At WFP Somalia we have a multi-skilled workforce & 3.27 & 1.21 \\
\hline
\end{tabular}

At 5\% sign. level

From the findings, the area where the organization's supply chain has performed best is in food quality. This is indicated by the fact that there have not been cases of diseases affecting the beneficiaries due to poor quality food supplies, with the highest mean of 3.69. This is followed by another aspect of quality where respondents agreed that WFP Somalia delivers defect free food supplies to beneficiaries, with a mean of 3.51. The organization's humanitarian supply chain has not performed well on dependability with whether WFP Somalia beneficiaries get food 
supplies when promised having the lowest mean of 2.90. According to Beamon and Balcik (2008), the primary goal in relief operations is to minimize the response time (to deliver supplies to the areas as they are needed). Moreover, relief efforts generally operate on limited funds, which increase the importance of efficient (low cost) inventory management systems. When disasters strike, relief organizations respond by delivering aid to those in need. Their supply chains must be both fast and agile, responding to sudden-onset disasters which may occur.

Multiple Regression Analysis

Table 12: Multiple Regression Analysis

\begin{tabular}{|c|c|c|c|c|c|}
\hline & \multicolumn{2}{|c|}{$\begin{array}{l}\text { Unstandardized } \\
\text { Coefficients }\end{array}$} & \multirow{2}{*}{$\begin{array}{c}\text { Standardized } \\
\text { Coefficients }\end{array}$} & \multirow[t]{2}{*}{$\mathrm{T}$} & \multirow[t]{2}{*}{ Sig. } \\
\hline & B & Std. Error & & & \\
\hline (Constant) & 0.853 & 1.068 & & 0.799 & 0.433 \\
\hline Information Sharing & 0.169 & 0.193 & -0.08 & -0.358 & 0.724 \\
\hline Multiple Tiers & 0.156 & 0.203 & 0.135 & 0.619 & 0.543 \\
\hline Knowledge Management & 0.128 & 0.250 & -0.242 & -0.891 & 0.383 \\
\hline $\begin{array}{c}\text { Supply Performance } \\
\text { Management }\end{array}$ & 0.205 & 0.16 & 0.346 & 1.284 & 0.213 \\
\hline Information Technology & 0.167 & 0.231 & 0.012 & 1.123 & 0.432 \\
\hline
\end{tabular}

At 5\% sign. level

Multiple regression analysis was done to determine the relationship between the WFP's Humanitarian supply chain performance and the five independent variables (Information Sharing, Multiple Tiers for Value Generation, Knowledge Management, Supplier Performance Management and IT integration) investigated in this survey. The regression equation ( $\mathrm{Y}=$ $\left.\beta_{0}+\beta_{1} X_{1}+\beta_{2} X_{2}+\beta_{3} X_{3}+\beta_{4} X_{4}+\beta_{5} X_{5}+\varepsilon\right)$ was:

$\mathrm{Y}=0.853+0.169 \mathrm{X} 1+0.156 \mathrm{X} 2+0.128 \mathrm{X} 3+0.205 \mathrm{X} 4+0.167 \mathrm{X} 5+0$

Whereby: $\mathrm{Y}=$ Performance (quality, cost, dependability, flexibility and cost) $\mathrm{X}_{1}=$ Information Sharing $\mathrm{X}_{2}=$ Multiple Tiers for Value Generation

$\mathrm{X}_{3}=$ Knowledge Management

$\mathrm{X}_{4}=$ Supplier Performance Management $\mathrm{X}_{5}=$

IT integration

At 5\% level of significance, the analysis shows that taking all other independent variables at zero, a unit increase in information sharing will 
lead to a 0.169 increase in humanitarian supply chain performance. A unit increase in Multiple Tiers for Value Generation will lead to a 0.156 increase in humanitarian supply chain performance; a unit increase in Knowledge Management will lead to a 0.128 increase in humanitarian supply chain performance; a unit increase in Supplier Performance Management will lead to a 0.205 increase in humanitarian supply chain performance while a unit increase in IT integration will lead to a 0.167 increase in humanitarian supply chain performance.

\section{Summary}

On information sharing, findings revealed that the organization always shares information with suppliers and that majority of the respondents said that information sharing greatly influences humanitarian supply chain performance. This is in agreement with Ounnar, Pujo, Mekaouche and Giambiasi (2007) who argued that organizations are beginning to understand and accept that if they do not open up to suppliers about their entire approach to cost investment return, it will be difficult for suppliers to contribute innovative ways to save money for both sides. With strategic information sharing between an organization and its suppliers, innovation is enhanced where suppliers are able to save significant money for an organization and share the cost savings for the benefit of all.

On multiple tiers valuation generation and humanitarian supply chain performance, results showed that WFP has multiple tier suppliers. This means that even though the organization had multiple supplier tiers for value generation, it did not know well the risk profile of each tier. It was also found that majority of the respondents think that multiple tiers greatly influence humanitarian supply chain performance. The findings are in agreement with Choy, Lee and Lo (2002) who posited that developing a collaborative relationship with a supplier does not occur overnight. It takes time to strengthen the various levels of communication. However, the same strategies that applied to an organization's first-tier supplier can also be applied to multiple tiers in the supply chain. As the market of tomorrow may be driven by competing supply chains, the ability to transfer those relationship skills to multiple tiers is a major advantage for organizations. Multi-tier supplier relationships are unique because they provide an opportunity for the organization and its suppliers to discuss mutual or company values (Shin, Collier \& Wilson, 2000).

On knowledge management and humanitarian supply chain performance, it was revealed that WFP continuously trains employees from then procurement department. This means the organization invests 
resources in the training of its employees in the procurement department. It was also found that majority of the respondents think that Knowledge Management influences humanitarian supply chain performance to a great extent.

WFP has mechanisms to ensure suppliers conform to quality standards and is keen on suppliers of critical commodities like food. The organization should check on the dependability of its services as beneficiaries do not get food supplies as they are promised. The findings agree with Tan, Kannan and Handfield (1998) who explained that measurement of supplier performance is a step in the right direction. Focusing on critical suppliers or suppliers that constitute the largest portion of spending enables a company to identify and manage those performance issues that could have the most immediate and greatest impact on its operations and its perception in the market.

IT is used in the execution and management of purchase orders and that majority of the respondents think that Information Technology influences humanitarian supply chain performance to a great extent. These findings are in agreement with Bowersox, Closs and Cooper (2002) who argued that the integration of technology in SRM applications allows co-operating parties to conceptualize and codify best practices into their interaction, as well as enforce compliance across multiple divisions and locations. SRM partners can use technology to allow each other to see information they might have kept secret from one another before, such as real-time changes in prices paid for components or changes in actual shipping costs (Bowersox, Closs \& Cooper, 2002).

On performance of WFP's humanitarian supply chain performance, results indicated that WFP Somalia delivers defect free food supplies to beneficiaries and that there are no cases of diseases affecting the beneficiaries due to poor quality food supplies. Results also showed that WFP Somalia beneficiaries do not get food supplies when promised. The findings are in agreement with Beamon and Balcik (2008) who posited that the primary goal in relief operations is to minimize the response time (to deliver supplies to the areas as they are needed). Relief efforts generally operate on limited funds, which increase the importance of efficient (low cost) inventory management systems. When disasters strike, relief organizations respond by delivering aid to those in need. Their supply chains must be both fast and agile, responding to suddenonset disasters which may occur (Beamon \& Balcik, 2008).

\section{Conclusion}

WFP shares information with suppliers, but the organization does not reward suppliers who share information. WFP has categorized its 
suppliers into multiple tiers but does not know the risk profile of each tier. WFP continuously trains employees from then procurement department but does not do much to encourage individual learning. The organization has put in place mechanisms to ensure suppliers conform to quality standards and that the organization is keen on suppliers of critical commodities like food. IT is used in the execution and management of purchase orders. WFP's humanitarian supply chain performance, results indicated that WFP Somalia delivers defect free food supplies to beneficiaries there are no cases of diseases affecting the beneficiaries due to poor quality food supplies but its services are not much dependable as beneficiaries do not get food supplies as they are promised.

\section{Recommendations}

Most humanitarian organizations share information with suppliers but they should go further and begin rewarding suppliers who share information in time as this will motivate them to continue doing so hence reduce quality problems and also reduce delivery time. It is not enough that organizations have multiple tier suppliers. Organizations should not only have multiple supply tiers but should also well understand each tiers risk profile. This will enable organizations mitigate any unforeseen events that may affect delivery of supplies especially during emergencies.

Organizations should also encourage individual learning. This will in turn enhance organizational learning and enable a culture of knowledge management which will increase the organizational supply chain performance. Learning organization begins from the individual. It is only when individuals in the organization learn that the whole organization learns. Organizations do not learn, individuals do. Organizations should also ensure the use of IT in all aspects of supplier relationship management if they have to realize an optimal humanitarian supply chain performance. Organizations should integrate software via the Web and the use of extendable markup language, which will make the technological problems much easier to deal with. Lastly, organizations should ensure that beneficiaries feel the organizations' services are dependable and deliver supplies as promised. The fundamental performance objectives that apply to all types of organizations and are closely related to customer satisfaction requirements are speed, dependability, flexibility, quality, and cost. If any of these objectives is not met, then the supply chain is obviously not performing well. This study investigated the effect of supplier relationship management on supply chain performance at the World Food Programme in Somalia. The researcher suggests that similar studies be conducted on other humanitarian organizations in the region so that generalizations can be 
done of effect of supplier relationship management on supply chain performance of humanitarian organizations in East Africa. It is also suggested that other studies be done to investigate the challenges facing humanitarian organizations in their supplier relationship management efforts. This will enable these organizations come up with ways of mitigating these challenges and hence increase the performance of their supply chains.

\section{References}

1. Appelfeller, W. \& Buchholz, W. (2005). Supplier relationship management. Strategie, Organisation und IT des modernen Beschaffungsmanagements, 12(2); 156-170

2. Batista, L. (2009). Key operations performance factors on trade and transport facilitation.

3. Beamon, B. M., \& Balcik, B. (2008). Performance measurement in humanitarian relief chains. International Journal of Public Sector Management, 21(1), 4-25.

4. Bhagwat, R., \& Sharma, M. K. (2007). Performance measurement of supply chain management: A balanced scorecard approach. Computers \& Industrial Engineering, 53(1), 43-62.

5. Bowersox, D. J., Closs, D. J., \& Cooper, M. B. (2002). Supply chain logistics management (Vol. 2). New York, NY: McGraw-Hill.

6. Cannon, J. P., \& Homburg, C. (2001). Buyer-supplier relationships and customer firm costs. Journal of Marketing, 65(1), 29-43.

7. Choy, K. L., Lee, W. B., \& Lo, V. (2002). Development of a case based intelligent customer-supplier relationship management system. Expert systems with Applications, 23(3), 281-297.

8. Clarke, W. S., \& Herbst, J. I. (Eds.). (1997). Learning from Somalia: the lessons of armed humanitarian intervention (p. 15). Oxford: Westview Press.

9. Cox, A. (2004). The art of the possible: relationship management in power regimes and supply chains. Supply Chain Management: An International Journal, 9(5), 346- 356.

10. Inkpen, A. C., \& Dinur, A. (1998). Knowledge management processes and international joint ventures. Organization Science, 9(4), 454-468.

11. Lascelles, D. M., \& Dale, B. G. (1989). The buyer-supplier relationship in total quality management. Journal of Supply Chain Management, 25(2), 10.

12. Laudon, K. C., \& Laudon, J. P. (2004). Management information systems: managing the digital firm. New Jersey, 8. 
13. Mettler, T. \& Rohner, P. (2009). Supplier relationship management: a case study in the context of health care, Journal of Theoretical and Applied Electronic Commerce Research 4(3), 58-71

14. Ounnar, F., Pujo, P., Mekaouche, L., \& Giambiasi, N. (2007). Customer-supplier relationship management in an intelligent supply chain network. Production Planning \& Control, 18(5), 377-387.

15. Paiva, E.L., Phonlor, P. \& D’avila, L.C. (2008). Buyer-supplier relationship and service performance: an operations perspective analysis, Journal of Production and Operations Management, 1(2), 7788

16. Samuel, I.I. (2014). An empirical study on the effect of buyersupplier partnership on better service delivery within nongovernmental organizations: a case of world vision international, European Journal of Business and Social Sciences, 3 (2), 44- 58

17. Shin, H., Collier, D. A., \& Wilson, D. D. (2000). Supply management orientation and supplier/buyer performance. Journal of operations management, 18(3), 317-333.

18. Simmel, G. (2011). Georg Simmel on individuality and social forms. University of Chicago Press.

19. Van Wassenhove, L. N. (2006). Humanitarian aid logistics: supply chain management in high gear†. Journal of the Operational Research Society, 57(5), 475-489.

20. WFP (2015). Accesses at http://www.wfp.org/about on 9 September 2015 